\title{
ПОШИРЕННЯ ТА ВІКОВА ДИНАМІКА КИШКОВИХ ПРОТОЗООЗІВ У ДОМАШНІХ ТВАРИН М. ХАРКОВА Р.Дубін ${ }^{1}$, О. Івлева ${ }^{2}$ \\ Одеський державний аграрний університет Луганський начіональний аграрний університет
}

У статті наведені результати досліджень фекалій собак у яких були виявлені найпростіші 5-х видів: Cystoisospora sp., Lamblia (Giardia sp.), Sarcocystis sp., Cryptosporidium sp., Trichomonas foetus; при дослідженні фекалій котів Giardia sp., Sarcocystis sp., C. rivalla, C. felis, ооцисти підродини Тохорlasmatinaе, активні форми джгутикових сімейства Trichomonadidae.

Ключові слова: собаки, коти, кишкові протозоози.

Постановка проблеми. Паразитичні найпростіші часто викликають важкі хвороби у своїх господарів. Кокцидії, паразитуючи в клітинах, викликають їх руйнування. У разі інтенсивного розмноження найпростіших йде масове ураження і відмирання клітин, що приводить до порушення функції органів. Крім руйнування клітин відбувається інтоксикація організму продуктами обміну речовин паразитів і розпаду тканин, що викликає ряд побічних явищ з боку серцево-судинної, нервової та видільної систем. Інвазії гіардіями не супроводжуються проникненням їх в клітини господаря, але тим не менше вони викликають порушення функціонування тонкого кишечника. Прикріплення гіардій викликає мікротравми ентероцитів, порушується пристінкові травлення, посилюються бродильні процеси, відбувається прискорення евакуації харчового субстрату. На тлі кишкових протозоозів можуть розвиватися різні алергічні реакції в організмі господаря $[1,4]$.

Широке поширення паразитичних найпростіших серед собак, котів та інших тварин, що утримуються в домашніх умовах в місті, обумовлено багатьма факторами. 3 одного боку, це пов'язано безпосередне з біологічними особливостями найпростіших i, в першу чергу, з їх високу стійкістю у зовнішньому середовищі, що забезпечує передачу інвазії від зараженої тварини здоровій. 3 іншого боку, створюються сприятливі умови не тільки для поширення кишкових найпростіших, але і занесення які раніше не реєструвались на території міста протозоозів через зростаючу міграцію тварин по країні і за кордон, збільшення популяції як диких, так і домашніх тварин, використання спільних 3 ними місць вигулу, порушення умов утримання тварин $[2,3,5]$.

В успішній терапії протозоозів важлива правильна діагностика, заснованная на визначенні виду найпростіших.

Для точного діагностування лямбліозу у собак необхідні знання діагностичних характеристик тесту та очікувана поширеності [6-9].

Метою наших досліджень було розробити комплекс сучасних методів диференційної діагностики та заходів боротьби з кишковими протозоозами собак та котів в умовах України.

Матеріали і методи досліджень Дослідницька робота проводилася на кафедрі інфектології, якості та безпеки продукції агропромислового комплексу Луганського національного аграрного університету та на базі ветеринарної клініки «Доктор Вет» м. Харків впродовж 2016-2020 рр.

Матеріалом для досліджень були собаки та коти віком від 1,5 до 12 місяців, хворі на діарею. Клінічне обстеження проводили загальноприйнятими методами. Для здійснення копрограми відбирали проби свіжих фекалій, виготовляли мазки: нативні, забарвлені розчином Люголя та розчином метиленового синього. Копрологічне дослідження проводили за методами Фюллеборна, флотації у розчині цукрози. Для виявлення ооцист робили тонкі мазки фекалій висушували, фіксували рідиною Нікіфорова та фарбували карбол-фуксином за Циль-Нільсеном. Кількісний підрахунок інтенсивності інвазії проводили методом Столла.

Результати власних досліджень У пробах фекалій, взятих від собак з клінічними ознаками ураження шлунково-кишкового тракту, за допомогою комбінованого флотаційного методу i подальшої мікроскопії нативних мазків виявлені найпростіші 5-х видів: Cystoisospora sp., Lamblia (Giardia sp.), Sarcocystis sp., Cryptosporidium sp., Trichomonas foetus. За досліджуваний період зараженість кишковими найпростішими домашніх собак склала 34,6\% (табл. 1). 
Таблиця 1.Екстенсивність інвазії кишковими протозоозами у собак

\begin{tabular}{|c|c|c|c|c|c|c|c|}
\hline \multirow{2}{*}{\multicolumn{2}{|c|}{ Показники }} & \multicolumn{5}{|c|}{ Роки } & \multirow[t]{2}{*}{ Усього } \\
\hline & & 2016 & 2017 & 2018 & 2019 & 2020 & \\
\hline \multicolumn{2}{|c|}{ Усього досліджено собак } & 325 & 380 & 425 & 450 & 490 & 2070 \\
\hline \multicolumn{2}{|c|}{3 них уражено, } & 82 & 111 & 149 & 144 & 144 & 630 \\
\hline \multicolumn{2}{|c|}{ Загальна кількість, \% } & 25,2 & 29,2 & 35,1 & 32,0 & 29,4 & 30,4 \\
\hline \multirow{5}{*}{$\begin{array}{l}\text { у тому } \\
\text { числі: }\end{array}$} & Cystoisospora sp. & 12,3 & 12,9 & 16 & 14,2 & 12,5 & 13,6 \\
\hline & Giardia sp. & 6,5 & 7,9 & 10,1 & 8,4 & 6,5 & 7,9 \\
\hline & Trichomonas foetus & 3,1 & 5,8 & 6,4 & 5,6 & 7,3 & 5,8 \\
\hline & Sarcocystis sp. & 1,8 & 2,1 & 2,1 & 2,9 & 2,5 & 2,3 \\
\hline & Cryptosporidium sp. & 1,5 & 0,5 & 0,5 & 0,9 & 0,6 & 0,8 \\
\hline
\end{tabular}

Як видно з таблиці 1, собаки на 30,4\% уражені кишковими найпростішими. На першому місці по частоті у собак виявляли найпростіші Cystoisospora sp. (EI 13,6\%), на другому - цисти Giardia sp. (EI 7,9\%), на третьому - Trichomonas foetus (EI 5,8\%). Рідше реєстрували Sarcocystis sp. (EI 2,3\%) і вкрай рідко Cryptosporidium sp (EI 0,8\%).

Кишкові найпростіші, в основному, паразитують у цуценят. Як показали наші дослідження, екстенсивність інвазії найпростішими у молодих тварин була вища ніж у дорослих тварин (рис. 1), причому найбільш часто у цуценят виявляли гіардіi та ізоспори.

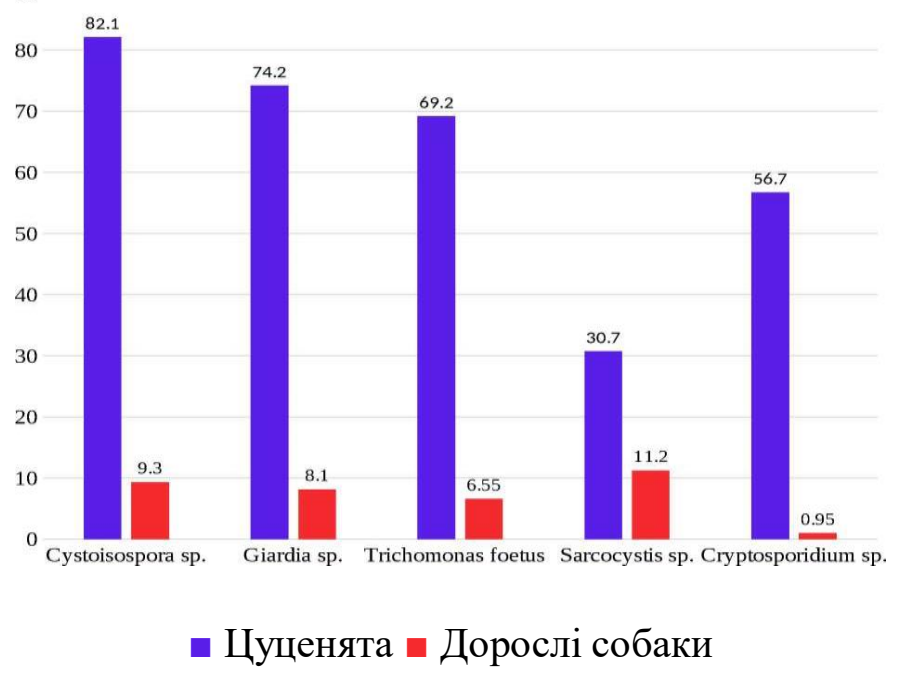

Рис. 1. Ураженість собак кишковими найпростішими в залежності від віку.

У котів нами зареєстровані Giardia sp., Sarcocystis sp., C. rivolta, C. felis, ооцисти підродини Toxoplasmatinae, активні форми джгутикових сімейства Trichomonadidae (табл. 4.2).

Таблиця 1.Екстенсивність інвазії кишковими протозоозами у котів

\begin{tabular}{|c|c|c|c|c|c|c|c|}
\hline \multirow{2}{*}{\multicolumn{2}{|c|}{ Показники }} & \multicolumn{5}{|c|}{ Роки } & \multirow[t]{2}{*}{ Усього } \\
\hline & & 2016 & 2017 & 2018 & 2019 & 2020 & \\
\hline \multicolumn{2}{|c|}{ Усього досліджено собак } & 215 & 226 & 250 & 230 & 240 & 1161 \\
\hline \multicolumn{2}{|c|}{3 них уражено, } & 56 & 66 & 85 & 74 & 72 & 353 \\
\hline \multicolumn{2}{|c|}{ Загальна кількість, \% } & 26 & 29,2 & 34 & 32,2 & 30 & 30,4 \\
\hline \multirow{4}{*}{$\begin{array}{l}\text { у тому } \\
\text { числі: }\end{array}$} & Giardia sp. & 13,5 & 15,04 & 17,2 & 14,4 & 12,5 & 14,6 \\
\hline & Cystoisospora sp. & 7,4 & 7,52 & 8,4 & 11,7 & 9,6 & 8,9 \\
\hline & Trichomonas & 4,2 & 5,31 & 7,2 & 5,2 & 6,7 & 5,8 \\
\hline & Sarcocystis sp. & 0,9 & 1,33 & 1,2 & 0,9 & 1,2 & 1,1 \\
\hline
\end{tabular}


Екстенсивність інвазії становила 30,4 \%. Найбільш часто у котів виявляли цисти Giardia sp. (екстенсивність інвазії склала - 14,6\%), рідше ооцисти Cystoisospora sp. (екстенсивність інвазії 8,9\%), вегетативні форми найпростіших сімейства Trichomonadidae (екстенсивність інвазії - 5,8\%) . Вкрай рідко знаходили спороцисти Sarcocystis sp. (екстенсивність інвазії 1,1\%). Зараженість кишковими протозоозами у котів в залежності від віку представлені у рис. 2.

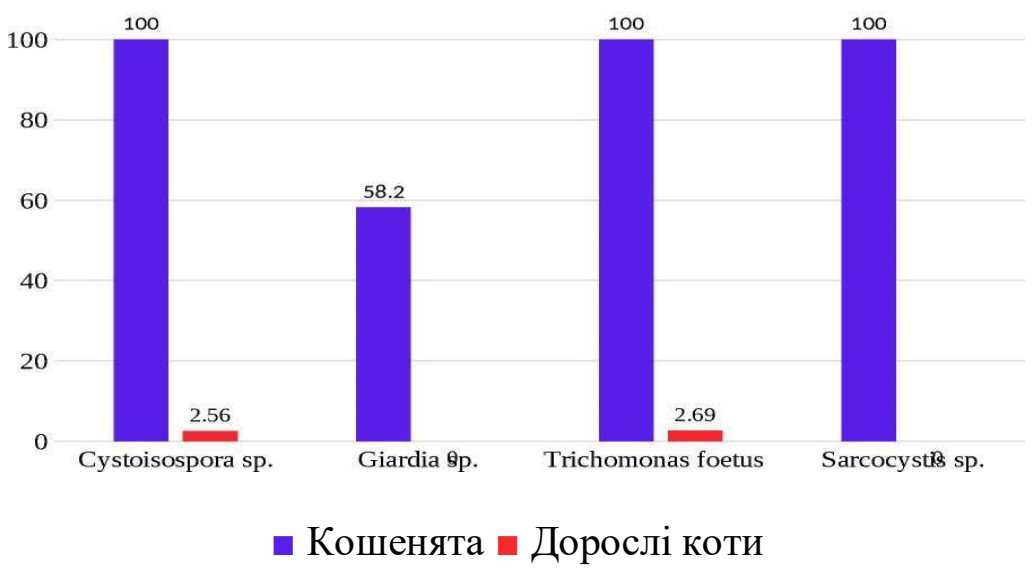

Рис. 2. Ураженість котів кишковими найпростішими в залежності від віку.

Згідно рис. 2. гіардіi, ізоспори, трихомонади та ізоспори реєстрували у кошенят. У дорослих котів зустрічалися спороцисти Cystoisospora sp. та вегетативні форми найпростіших сімейства Trichomonadidae. Серед протозойних хвороб у собак найбільш поширений цистоізоспороз $(15,4 \%)$. Цистоізоспорози реєстрували у молодих тварин у віці 1,5-3 міс і рідко ооцисти виділяли у дорослих котів і собак. Інтенсивність інвазії варіювала від декількох десятків ооцист до декількох тисяч в 1 г фекалій. Цисти гіардій виявляли часто у молодняку собак, котів. Інтенсивність інвазії варіювала від декількох десятків до декількох тисяч цист в 1 г фекалій.

Поширення гіардіозу серед молодих тварин пояснюється біологічними особливостями гіардій, для паразитування яких необхідною умовою $\epsilon$ наявність хорошого пристінкового травлення. Передача саркоцист відбувається за участю проміжного господаря, тому собаки заражаються саркоцистами при згодовуванні їм сирого м'яса або при поїданні гризунів. Саркоцисти у котів зустрічаються рідше, що пов'язано з годуванням котів, в основному, сухими і консервованими кормами. У собак і котів зафіксовано низьку інтенсивність інвазії: від однієї до кількох сотень ооцист в 1 г фекалій. У тварин, в фекаліях яких були виявлені ооцисти саркоспорідій, як правило, не спостерігалося змін з боку травного тракту і загального стану.

Висновки та перспективи подальших досліджень На підставі проведених в 2016-2020 pp. копрологічних та лабораторних досліджень фекалій було виявлено, що в харківській популяції собак і котів найбільш широко поширені ізоспороз (EI 8,9-13,6\%), лямбліоз (EI 7,9-14,62\%) i трихомоніаз (ЕI 5,8\%). Криптоспорідіі за весь період досліджень були виявлені в поодиноких випадках (EI 0,8\%). В подальшому планується провести гематологічні та біохімічні дослідження крові тварин за кишковими протозоозами. Також провести ефективність застосування різних лабораторних методів для виявлення хворих тварин за кишковими протозоозами.

\section{Список використаних джерел}

1. Sun Z, Stack C, Slapeta J. Sequence differences in the diagnostic region of the cysteine protease 8 gene of Tritrichomonas foetus parasites of cats and cattle. Vet Parasitol 2012; 186(3-4): 445-449.

2. Walden HS, Dykstra C, Dillon A, Rodning S, Givens D, Bird R, et al. A new species of Tritrichomonas(Sarcomastigophora: Trichomonida) from the domestic cat (Felis catus ). Parasitol Res 2013; 112(6): 2227-2235.

3. Morin-Adeline V, Lomas R, O'Meally D, Stack C, Conesa A, Slapeta J. Comparative transcriptomics reveals striking similarities between the bovine and feline isolates of Tritrichomonas foetus: consequences for in silico drug-target identification. BMC Genomics 2014; 15(1): 955.

4. Tachezy J, Tachezy R, Hampl V, Sedinovâ M, Vanacovâ S, Vrifk M, et al. Cattle pathogen Tritrichomonas foetus(Riedmuller, 1928) and pig commensal Tritrichomonas suis (Gruby \& Delafond, 
1843 ) belong to the same species. J Eukaryot Microbiol 2002; 49(2): 154-163.

5. Lun ZR, Chen XG, Zhu XQ, Li XR, Xie MQ. Are Tritrichomonas foetus and Tritrichomonas suis synonyms? Trends Parasitol 2005; 21(3): 122-125.

6. Gookin JL, Hanrahan K, Levy MG. The conundrum of feline trichomonosis. J Feline Med Surg 2017; 19(3): 261-274.

7. Pereira-Neves A, Ribeiro KC, Benchimol M. Pseudocysts in trichomonads - new insights. Protist 2003; 154(3-4): 313-329.

8. Pereira-Neves A, Benchimol M. Tritrichomonas foetus: budding from multinucleated pseudocysts. Protist 2009; 160(4): 536-551.

9. Rosa IA, Souza W, Benchimol M. Changes in the structural organization of the cytoskeleton of Tritrichomonas foetus during trophozoite-pseudocyst transformation. Micron 2015; 73: 28-35.

\section{РАСПРОСТРАНЕНИЕ И ВОЗРАСТНАЯ ДИНАМИКА КИШЕЧНЫХ ПРОТОЗООЗОВ В ДОМАШНИХ ЖИВОТНЫХ г. ХАРЬКОВА.}

Дубин Р., Ивлева А.

В статье приведень результаты исследований фрекалий собак у которых были обнаружены простейшие 5-х видов: Cystoisospora sp., Lamblia (Giardia sp.), Sarcocystis sp., Cryptosporidium sp., Trichomonas foetus; при исследовании фекалий кошек Giardia sp., Sarcocystis sp., C. rivalla, C. felis, ооцисты подсемейства Toхорlasmatinae, активные формы жсутиковых семейства Trichomonadidae.

Ключевые слова: собаки, кочки, кишечные протозоозы.

\section{DISTRIBUTION AND AGE DYNAMICS OF INTESTINAL PROTOZOSIS IN DOMESTIC ANIMALS, KHARKOV.}

Dubin R., Ivleva O.

In The article presents the results of studies of feces of dogs in which the simplest 5 species were found: Cystoisospora sp., Lamblia (Giardia sp.), Sarcocystis sp., Cryptosporidium sp., Trichomonas foetus; in the study offeces of cats Giardia sp., Sarcocystis sp., C. rivalla, C. felis, oocysts of the subfamily Toxoplasmatinae, active forms of the flagellar family Trichomonadidae.

Key words: dogs, cats, intestinal protozoa. 